\title{
THE ARAB SPRING, GOOD GOVERNANCE AND CITIZENS' RIGHTS
}

\author{
Elmira Akhmetova*
}

\begin{abstract}
This article is a study of the origins and consequences of the Arab Spring through highlighting the higher objectives of the Shariah in governance, as well as the basic rights and responsibilities of the citizens and the rulers in Islam. The paper suggests that maintaining peace, harmony and social stability are the main objectives of Islam in governance. But revolutionary changes commonly destroy social harmony and well-being; and produce chaos, insecurity, injustice and economic collapse. At the same time, the citizens own rights to disobey their deviant rulers. Accordingly, through discussing the rights and responsibilities of the citizens before their rulers and of the rulers before their people, the paper recommends adoption of the approach of nonviolent and evolutionary changes to improve political and social ills. It also suggests that governments should conduct peaceful, fair-minded and just rule rather than giving people no other option but to create public havoc. The paper also suggests that Islamic principles in governance, as embedded in the text and traditions, are conducive to good governance and democratic thought in many compelling ways.
\end{abstract}

\section{Introduction}

The Arab Spring is a manifestation of the absence of good governance in the Middle Eastern and North African (MENA) countries. For decades, the citizens of these post-colonial nation states were suffering from an unending cycle of despotism, economic and political exploitation, poverty and public cruelty. Global media highlighted the series of mass eruptions and instability occurring throughout the region since October 2010 as an arrival of a Western type of democracy and good governance in the Muslim World. When Egyptian president Hosni Mubarak relinquished power on 11 February 2011, it was claimed that for thirty years he had tyrannised the people of Egypt, and now in their righteous wrath, the citizens came to understand democracy, and wanted to achieve democracy. ${ }^{1}$ On 31 March 2011, an American columnist, Declan McCullagh, enthusiastically commented in The Economist, that democracy is becoming a reality in a number of Muslim countries. Yet, he raised concerns on the future of democracy in the Muslim world due to the restoration of Islam in politics, as he skeptically stated:

Now, however, there are signs that Islam is a growing force in the Arab revolutions. That makes secular-minded and liberal people, both Arabs 
and Westerners, queasy. They fear that the Arab awakening might be hijacked by the sort of Islamists who reject a pluralist version of democracy, oppress women and fly the flag of jihad against Christians and Jews. ${ }^{2}$

Declan McCullagh was right in presuming the emergence of the previously outlawed Islamist parties as major political players in the post-Spring governance. On 23 October 2011, Tunisian citizens voted in the first post-revolution election, where the formerly banned Islamist party Ennahda, also known as the Renaissance Party, won 37 per cent of the total vote and 89 seats (out of 217) in the Tunisian Constituent Assembly (41 per cent), and managed to elect forty-two women. On 30 June 2012, Mohamed Morsi, a leading member in the Muslim Brotherhood, was sworn in as Egypt's first democratically elected president. Yet, the flag of jihad did not fly against Christians and Jews. On 2 December 2011, during his run for the presidential elections, Morsi shared his stance towards non-Muslims with Dream TV. He said: "We are commanded, by God Almighty, to respect others' faiths, just as we respect our own. God Almighty granted all people the right and freedom to believe. People are free to believe in God or not to believe, not only Muslims or Christians. If God gave the people the right to freedom in such a tremendously important matter, what about less significant rights and freedoms?! They are obviously guaranteed." 3

One year later, on 3 July 2013, Morsi was brutally overthrown by a military coup in the name of democracy and the demands of the Egyptian people. Since then, political turmoil has deepened in Egypt. Security forces have killed hundreds of Muslim Brotherhood members in the streets, and arrested thousands of others. On 24 March 2014, an Egyptian court sentenced 529 members of the outlawed Muslim Brotherhood to death on charges including violence, inciting murder, storming a police station, attacking persons, and damaging public and private property. ${ }^{4}$

A Western-type of democracy and liberalism have not become a reality either in Egypt or in other post-Spring MENA countries, except in Tunisia. Before bearing any benefits, the Arab Spring generated widespread chaos, civil wars, bloodshed and insecurity. Thousands paid the ultimate price for regime overthrow. Human rights groups reported up to 194,702 deaths (80 per cent in Syria) around the region since the start of popular uprisings. Due to the chaotic nature of each nation's conflict, many of the mortality rates are rough estimates. Economic and social welfare systems entirely collapsed as well.

Then, how may such violence and anarchy be justified in the name of democracy and liberalism? What are the main objectives of democracy and good governance then? Also, are the problems of human insecurity and well- 
being directly related to the restoration of Islam in the politics of the post-Spring MENA countries? What are the fundamental objectives and main principles of Islam in governance? Consequently, this essay attempts to respond to these questions by highlighting the basic objectives of the Shariah in governance, and the basic rights and responsibilities of the citizens and rulers in Islam.

\section{Islam and Good Governance}

The term good governance is a civilian concept. It basically centres on the responsibility of governments and governing bodies to meet the needs of the populace as opposed to select groups in society. It originated in a 1989 World Bank document entitled Sub-Saharan Africa: From Crisis to Sustainable Growth. Within the context of this record, the notion of good governance was directly associated with the types of structural economic adjustment policies that the World Bank had been advocating for many years: reduced state intervention in economic decision-making; reduced public sectors and more efficient and transparent public sector administration; freer markets and the elimination of unnecessary public subsidies; and increased integration into the world economy generally. ${ }^{5}$

Since then, the concept of good governance has been expanded by the World Bank and other international aid donors, non-governmental organisations, academicians, and Western governments and politicians to include all of the following: economic liberalisation and the creation of market friendly environments; transparency and accountability with respect to both economic and political decision-making; political liberalisation, particularly democratic reforms; rule of law and the elimination of corruption; the promotion of civil society; the introduction of fundamental human rights guarantees, especially with respect to political rights such as freedom of expression, freedom of assembly and freedom from arbitrary imprisonment; and the adoption of policies designed to safeguard long-term global interests like education, health and the environment. ${ }^{6}$

At present, the concept of good governance covers a broad spectrum, allowing different cultures and organisations to develop their own institutions and mechanisms for social reforms, and to frame their respective interpretations of the term in divergent ways. This paper attempts to comprehend the good governance paradigm in the particular case of Islam and implementation of its tenets in the contemporary Muslim world.

The system of rule that the Qur'an has envisaged is founded in the following principles such as: trust (amānah), justice ('adālah), consultation (shürā), the rule of law or the Shariah, pledge of allegiance (bay'ah), the principle of vicegerency (khiläfah), representation (wakālah), and bidding good and forbidding evil (amr bi'l-ma'rüf wa-nahy 'an al-munkar). 
The establishment of public welfare and concern for the public interest are among the most important functions of good governance. In Islamic jurisprudence, the principles of good governance appear under the concept of siyassah shar' $\bar{l} y a h$. Siyāsah shar' iyah is a broad doctrine of Islamic law which authorises the ruler to determine the manner in which the Shariah should be administered. Literally siyāsah shar' 'yyah means a Shariah-oriented policy, or government in accordance with Shariah. It applies to all government policies, be it in areas where the Shariah provides explicit guidance or otherwise. ${ }^{7}$

In the usage of the fuqah $\bar{a}^{\prime}$, siyassah shar' $\bar{l} y a h$ denoted decisions and policy measures taken by the imam and the ulu al-amr on matters for which no specific ruling can be found in the Shariah. In that connotation, siyāsah shar 'iyah is equal to acting on maslahah, or public interest, which the Lawgiver has neither upheld nor overruled. ${ }^{8}$ Accordingly, siyāsah shar' $\bar{y}$ ah denotes the "administration of public affairs in an Islamic polity with the aim of securing the interest of, and preventing harm to, the community, in harmony with the general principles of the Shariah, even if this disagrees with specific rulings of the mujtahids." concept of siyāsah shar' 'iyah, including its meaning, mechanisms and functions, has developed over centuries in the works of the fuqaha ' and the Qur'anic guidance was constantly implemented to guarantee public interest.

Government in Islam is an essential component of God's trust (amānah) to mankind. The government must guarantee the rights of every individual under its authority. Its primary function is to ensure the well-being and security of the people, and to establish peace and justice in society. A ruler may accordingly take discretionary measures, enact rules and initiate policies as he deems appropriate in the interests of good government, provided that no substantive principle of the Shariah is thereby violated. ${ }^{10}$

In the early days of the institution of the caliphate, the leader, acting as both spiritual and political guide of the community, had to rule on the basis of the trust delegated to him by God and also by the members of the community, who could publicly monitor his activities. The leader acknowledged that he was not the ruler but the servant of the people and his job was to work for the well-being of the entire society, that all his decisions, actions and policies were guided by the criteria of public interest and that he was accountable to the society and to God. The leadership did not have to come from any royal family or aristocracy: talent, character, sincerity, integrity and commitment to God's guidance were the main criteria for leadership. ${ }^{11}$

Accountability of the government (muhāsabah) is one of the fundamentals of the Islamic concept of rule. Muhāsabah as a principle of government has been concerned with political and financial matters and the abuse of authority for selfish purposes. As Mohammad Hashim Kamali observes, the principle of 
accountability in the Shariah basically draws no distinction between government leaders and other members of the community and renders them all accountable for their conduct. Everyone is responsible for what they do regardless of his/her social or political status. According to Kamali, this is because all the evidence that is found in the Qur'an and Sunna on personal accountability of individuals is conveyed in general (' $\bar{a} \mathrm{~mm}$ ) terms which makes no exception in favour of anyone. $^{12}$

The Islamic government is obliged to conduct the community affairs through consultation $(s h \bar{u} r \bar{a})$ with the community and their representatives. In that sense, consultation involves a certain degree of accountability to the public as well as their participation and involvement in decision-making. ${ }^{13}$

In sum, ensuring peace, justice, harmony and social stability are the fundamental objectives of governance in Islam. To achieve these aims, the government must guarantee the rights of every individual under its authority and should secure public participation in decision-making. It follows that there is no essential incompatibility between the ultimate aims of the good governance paradigm and Islamic political theory envisaged in the Qur'an and Sunna. In the following pages, I discuss the relevance of good governance in the contemporary Muslim world.

\section{Current Scenario of the Muslim World}

The Muslim world is currently experiencing a period of significant political, economic and social transition. It is shaken badly by large-scale bloodshed, political upheavals, poverty and economic depression. The soul of the ideal Islamic state, which is closely in line with the Western concept of good governance, is lost in reality in the modern Muslim world. In fact, the Qur'anic model of governance never accomplished its paramount objectives and far-reaching potential except during the rule of the Prophet [peace be upon him]) and the righteous caliphs. Following this period the Islamic caliphate existed in form rather than substance, simply passing political authority from one state to another, and from one dynasty to another.${ }^{14}$ Since the establishment of the Umayyad dynasty in $661 \mathrm{CE}$, the entire Muslim world, with rare exceptions, suffered from despotic and authoritarian regimes, the evils of nepotism, corruption and injustice, endless political turbulences and wars, and the negligence of the citizens' basic rights.

Since the early days of the Islamic political establishment, Muslim societies strived to find appropriate mechanisms to protect the citizens' rights and their independence from authority, by rooting this in the Qur'anic principles and the Sunna. The result was the creation of the judiciary as an independent institution from the executive power to enforce justice and order in society. The first independent judges for Muslim provinces were appointed as early as during the 
rule of 'Umar ibn al-Khațtāa (r. 634-644), the second righteous caliph. These judges were completely independent from the regional governors but were under the direct supervision of the caliph. The same policy was continued during the Umayyad dynasty as judges were given a freehand without any restrictions from the executive power including that of the caliph himself.

During the reign of Harūn al-Rashīd (r. 786-809), the famous Abbasid caliph, the post of the $Q \bar{a} d \bar{l}$ al-Qudqat, judge of judges, was created and entrusted to Ya qūb ibn Ibrahīm al-Anșāiñ, known as Abū Yūsuf (d. 798). The whole judiciary consequently came under Abū Yūsuf's supervision, including the appointment and dismissal of governors, following up with court rules pertaining to them, and all judicial matters attached to the governors, without any interference from the caliphs or their assistants. ${ }^{15}$

For many centuries, this mechanism of the judiciary worked effectively in different parts of the Muslim world in line with its original principles of being independent from the executive power, and protected the rights of the populace without any religious or ethnic discrimination. The Shariah highly emphasises on the equality of all in front of the law, regardless of their religious beliefs, or social or political standing. Even when the rulers wanted to transgress the power of the judiciary, they knew perfectly well that they would face not just the judicial institution, but the whole public, who were keen on the judges' independence and saw in any disobedience of judiciary rule a challenge to themselves. In such way, the Muslim populace was able to maintain their rights and to face their rulers in the cases of despotism or injustice.

The colonial age destroyed this very spirit of tranquillity in Muslim societies, including the old-aged communal mechanisms of preservation of justice and human dignity. Following the decolonisation strategy of the post-World War II period, various nation-states began to emerge in the Muslim world in the name of ethnic nationalism. At present, there are more than fifty Muslim nation-states, extending from the Atlas Mountains in the West to the Malay Archipelago in the East, and from Sub-Saharan Africa to the steppes of Central Asia. This division of the Muslim world into various nation-states, however, reflected largely the interests of their colonial powers. The authorities, who were responsible for drawing the territorial borders of the nation-states in the Muslim world, paid almost no attention to ethnic and religious peculiarities, and the will of the people living within these boundaries.

Very soon, territorial divisions became a source of tension between newly decolonised Muslims states that claimed mutually exclusive rights to the same territories. As Vali Reza Nasr, a leading expert on the Middle East and Dean of the Johns Hopkins School of Advanced International Studies in Washington DC, noticed, the colonial powers drew boundaries but did little to unify the peoples 
that fell within them into a national culture. At times they even did the opposite; and sought to maintain their control by encouraging competition between ethnic, linguistic, religious, or tribal groupings. ${ }^{16}$ Unresolved tensions between peoples and regions continue to be one of the main problems in the modern Muslim world, frequently leading to bloody clashes that have escalated sharply in the last several decades. It seems that the ideology of nationalism was an ineffective answer to the problems existing in the Muslim world, and brought about more enmity and antagonism, contributing greatly to sectarian, ethnic as well as ideological conflicts in the contemporary Muslim World.

Imperial powers left their former colonies into the hands of local marionette governments, which, due to their spinelessness and vanity, depended persistently on the will of their former masters. In effect, the contemporary Muslim world is shaped by the ills and misdeeds of the past and continues being influenced by intrigues of the foreign powers. Overwhelmingly, countries in the third world never really achieved their complete independence. The legacy of colonialism continues to shape and reshape their politics, tactics, economics as well as societies. Colonialism also survived in the forms taken by state ideologies, political visions, and institutions. ${ }^{17}$ At the same time, most of the nation-states in the Middle East and North Africa failed to merge their cultural, religious and regional peculiarities positively into the politics, state ideologies and systems.

Most of the Middle Eastern and North African Muslim countries are governed by monarchies, which failed to respond to the needs and opportunities of their own people, or to create a milieu of public trust, appreciation and sincerity between the political elite and the people. Within two decades or slightly more, the legitimacy of the ruling families to represent the entire populace became a crucial subject in many Muslim states. Piecemeal economic and political reforms were introduced, to varying degrees, within many countries in the region, as a means of meeting the challenges experienced by the ruling power. Yet, Muslim states today are a long way from having even a minimal level of democracy. No countries in the Muslim world were rated as having a "full democracy" under the guidelines of the Democracy Index, compiled in 2010 near the beginning of Arab Spring by the Economist Intelligence Unit; and only three out of forty-nine Muslim-majority countries were rated as a "flawed democracy." The rest were rated either an "authoritarian regime" or a "hybrid regime." 18

The modern type of electoral process as well as other Western-style democratic mechanisms of decision-making to the MENA region also went wrong. Most of the despotic rulers in the Middle East claim to have been democratically elected. These elections, however, were not transparent, and were influenced or manipulated by their former colonial or other Western powers.

Furthermore, evils like corruption, nepotism, injustice or chauvinism are 
widespread in Muslim societies. The results of the Corruption Perceptions Index (CPI) 2013, prepared by Transparency International, warn that the abuse of power, secret dealings and bribery wreck the individual and public wellbeing within the Muslim world. It ranked many Muslim countries as having the highest perceived levels of corruption in the world. The latest Index in 2013 scored 177 countries and territories on a scale from 0 (highly corrupt) to 100 (very clean). In that list, the ten bottom countries which were ranked as most corrupted, excluding North Korea, are Muslim-majority countries. Somalia and Afghanistan, along with non-Muslim North Korea, made up the worst performers in the year, scoring just 8 points each, followed by Sudan (11 points), South Sudan (14 points), Libya (15 points), Iraq (16 points), Uzbekistan, Turkmenistan and Syria (17 points each). Only three Muslim-majority countries score above 50: United Arab Emirates (69 points), Qatar (68 points) and Brunei (60 points). ${ }^{19}$ Such disappointing figures do not evoke hope for a quick recovery in the Muslim world. Muslim nation-states are far distant from achieving the fundamental objectives of governance in Islam. The most disturbing realities, however, are related to the issue of citizens' rights in these countries, which I discuss in the following pages.

\section{Citizens' Rights in Islam and Current Realities}

The recent outbreak of the Arab Spring is a collective struggle of the masses for their basic civilian and human rights. Overall, the post-colonial governments in the MENA region failed to ensure the well-being and security of their citizens. International watchdogs often raise concerns on various cases against human rights, including pervasive political censorship, police brutality, arbitrary detention, torture, and restrictions on freedom of religion, speech, association, and assembly. Poverty, malnutrition and lack of health security are also among the foremost problems of the MENA countries. The region is home to about seventy million of the world's poor (living on less than two dollars per day) and twenty million of the world's extremely poor (living on less than US $\$ 1.25$ per day). Despite possessing 70 per cent of the world's energy resources and 40 per cent of its natural resources, the gross domestic product (GDP) of all member states of the Organisation of Islamic Cooperation (OIC) is less than that of Japan. The challenges which the MENA governments are facing today are immense, and a quick and proper response from the authorities is urgently required. The concept, principles and structure of governance, including its philosophy and fundamentals, needs to be reviewed and comprehended by the authorities.

The actual spirit of Islamic principles of governance, which had been established by Qur'anic commands and the deeds of the Prophet [peace be upon him] and exercised by the righteous caliphs, is gone. In the early period of Islamic history, the leader acknowledged that he was not the ruler but the servant of the 
people and his job was to work for the well-being of all in society, that all his decisions, actions and policies were guided by the criteria of public interest and that he was accountable to the society and to God. ${ }^{20}$ The primary function of the government in Islam thus is to ensure the welfare and security of the people, and to establish peace and justice in society. To realise these aims, the government must guarantee the rights of all citizens under its authority, regardless of their gender, age and religious, social or ethnic backgrounds.

There are at least six basic rights the citizen enjoys in an Islamic polity: the right to vote; the right to nomination for political office; the right of consultation in the affairs of the government; the right to express an opinion on political matters; the citizen's right not to obey a deviant ruler; and, lastly, the right to health, welfare, occupation and education. ${ }^{21}$

Every citizen of an Islamic polity is entitled to participate in the election of the ruler and other representative government bodies. Once the head of the government is lawfully elected, he is under an obligation to consult the community in government affairs. The principle of consultation, or shürā in Arabic, embraces every facet of life and is easily adaptable to a variety of different situations. According to Kamali, it is a "collective right of the community and those of government." ${ }^{22}$ Accordingly, Islamic government is participatory and consultative; its mechanism of consultation contemplates a dynamic and fervent participation of the populace in a varied strata of state affairs.

In addition, the citizen of an Islamic polity enjoys the right to criticise and to express his/her opinion on the conduct of government as well as political matters. This right is manifested in the prominent Qur'anic principle of hisbah, which means promotion of good and prevention of evil (amr bi'l-ma'rüf wa-nahy 'an al-munkar). Under hisbah, no individual in the state, regardless of his/her gender, religious belief or social strata, can be prohibited from promoting a good cause or putting a stop to an evil one. In addition, Islam gives people the right to freedom of association and to the formation of parties or organisations, provided that this right is exercised in spreading virtue and righteousness, not to spread evil and mischief.

Next, citizens have the God-given right to protest peacefully against the government's tyranny as well, whether that abuse is directed against individuals, groups, or the entire population. In Islam, once the head of the government is lawfully elected, the citizen is normally obliged to obey him and to remain loyal to him. In surah al-Nisā', God demands obedience to the lawful government when he addresses the believers accordingly: "O you who believe! Obey Allah and obey the messenger and those of you who are in authority" (al-Nisä', 4:59). This loyalty, however, is not unconditional. When the lawful authorities violate the law and conduct acts of transgression or fail to fulfil their responsibilities 
as the legislative representatives of the country, then the citizens are entitled to decide whether to obey the deviant authorities or not. Different approaches are required with regards to different types of deviant governments and the circumstances involved. ${ }^{23}$

Mohammad Hashim Kamali maintains that in situations other than a clear declaration of unbelief ( $k u f r)$ and renunciation of Islam, defiance of lawful authority must never be brought about by armed rebellion on the part of a minority within the community. ${ }^{24}$ Prophet Muhammad [peace be upon him] had forewarned at two junctures about this by saying that: "He who raises arms against us ceases to be one of us," ${ }^{25}$ and "He who unleashes his sword against us ceases to be one of us." ${ }^{26}$ Islam generally is for stability, peace and public order, and there is no space for the overthrow of the lawful government by a minority group. The devices in the Islamic political system of the citizens' rights to criticise the authorities, to participate in the electoral process and consultation (shürā) and freedom of expression provide suitable room for constructive improvements in state affairs.

Therefore, provisions for public welfare and consideration of the public interest are among the most important functions of governance. Protection of human life and dignity is a fundamental objective and principle of Islamic teachings. Islam thus entitles all citizens to the provision of the basic necessities of life without any distinction of caste or belief. The right to basic necessities embraces the right to employment and assistance to find an appropriate occupation as well. It is the responsibility of the state to provide an organisational structure through a well-established judicial system, administrative control and a security system necessary for a peaceful co-existence of citizens.

In sum, the government must guarantee all the previously mentioned rights for every individual under its authority. It should ensure the well-being and security of the people, and establish peace and justice in society. If the regime fails to fulfil these main objectives of Islamic governance, then the citizens have rights to contribute towards change, but, in this writer's view, the main Islamic principles of keeping peace and public order should be preserved.

\section{Arab Spring and Its Aftermath}

The 'Arab Spring' is often identified as the birth of a "collective Arab consciousness." ${ }^{27}$ This revolutionary wave of mass demonstrations and protests (both violent and non-violent), riots and civil wars in the Middle East and North Africa was sparked by the suicide attempt of a young Tunisian street fruit vendor, Mohamed Bouazizi, on 18 December 2010. Becoming extremely frustrated due to police corruption, discrimination and ill treatment, Mohamed Bouazizi immolated himself in public. When he died in hospital several weeks later, the flame of public 
rage rapidly engulfed Tunisia and most of the Arab world within days, transforming the politics of the region and ousting even the best entrenched dictators.

Ten days after the death of Bouazizi, President Zine el Abidine Ben Ali's twenty-three-year rule of Tunisia ended. Colonel Muammar Gaddafi, who ruled Libya for forty-two years, was killed by rebel fighters in October 2011, eight months after government clashes with protesters escalated into a nationwide civil war. Ali Abdullah Saleh, Yemen's President for thirty-three years stepped down in February 2012 after months of massive nationwide protests. Hosni Mubarak of Egypt, who ruled the country for twenty-nine years, was overthrown in a mass uprising in February 2011.

The Arab Spring, indeed, brought a significant change to the entire MENA region. Both the positive and negative facets of this political outbreak have extensively been elaborated by scores of academicians, political scientists, journalists and writers. In this article, I would like to discuss the four most essential aspects only.

Firstly, the full episode of the Arab Spring confirmed the strength of the will of the masses. Upheavals across the MENA region were sparked mainly because of the negligence of citizens' rights by the respective governments. For decades, the region has been exploited by those who hunted for controlling the resources and wealth of the nations, with no concern for their people's will. The citizens' rights to participate in decision-making processes were mostly ignored. They were not given any opportunity to amend the unfair systems through peaceful means endorsed by the Shariah, such as by participation in fair elections, consultation, the assessment of the conduct of the government, and freedom of expression. The MENA population is exhausted from the unending cycle of despotism, economic and political exploitation, poverty and public cruelty. They opted for change, and, certainly, for a quick and substantial change.

Besides, the Arab Spring manifested the potential of the youth. Already in March 2011, in the early days of the Arab Spring, Declan McCullagh illustrated the political disruption in the MENA region as the "sight of corrupt old Arab tyrants being toppled at the behest of a new generation of young idealists, inspired by democracy, united by Facebook and excited by the notion of opening up to a wider world. ${ }^{28}$ No doubt, youth are the most optimistic and assertive stratum of every society, and they played the major role in the Middle Eastern transformation. In addition, the youth represent a significant portion of the MENA population. At present, more than half of the Muslim population is under the age of twenty five, and the needs and wants of such a significant portion of society should not be neglected. For decades, however, Arab youth remained marginalised and isolated and excluded from decision making process. They have been the most frustrated stratum in their societies with the methods of governance. 
Secondly, the political transformation and the elections did not mark the end to post-colonial dictatorship and despotism. The Arab Spring caused structural changes that shook the Arab swamp. Before bearing any benefits, it generated widespread chaos, civil wars, bloodshed and insecurity. It has now opened a door that could lead toward either stability and advancement, or regression and destruction. Evils of sectarianism and tribalism have appeared too clearly and are now threatening societal and state unity in the entire region. The conflict in Syria, for instance, which began as peaceful demonstrations against the Ba'ath regime under President Bashar Al-Assad, soon turned into a civil war with sectarian and tribal dimensions. According to the Britain-based Syrian Observatory for Human Rights report, at least 160,000 people were killed in the Syrian conflict between March 2011 and May 2014, many of whom were civilians and children. ${ }^{29}$ The real figure is likely to be much higher. Ceasefire attempts by the United Nations and the 2012 peace plan of Kofi Annan, the former UN Secretary-General, practically collapsed, with infractions of the ceasefire by both sides resulting in thousands of casualties.

According to a Lebanese journalist and editor in chief of the Tahawoulat newspaper, Sarkis Abu-Zayd, the conflicting parties in Syria are bound by tribal rather than religious or sectarian cohesion. In the cases of Libya and Yemen too, with the Arab Spring, tribal conflicts that were inherent in the social fabric floated to the surface. As Abu-Zayd pointed out, tribal clashes in various Libyan regions have today reached a point that threatens secession and the establishment of a tribal federation, which will likely be accompanied with chaos, massive loss and terror. ${ }^{30}$

In Egypt, the earliest attempts of democracy also failed. Field Marshal Abdel Fattah el-Sisi overthrew the first democratically elected president in the entire history of Egypt, exterminated those who opposed him and paved the way for his absolute rule. Ironically, Sisi claims that his actions against the Egyptian people were all done in response to the demands of the Egyptian people. A new cycle of military dictatorship might become a reality in Libya as well. ${ }^{31}$

Thirdly, the Arab Spring did not signify the arrival of a Western-type of democracy and liberalism in the Muslim world either. People in the post-Spring countries are subjected to widespread social and economic instability, poverty, injustice and discrimination. It seems that the change of a ruler or government alone may not improve the situation and establish democratic systems.

Ibrahim Alloush, Professor at Zaytouna University in Jordan, while speaking about the situation in Libya after the murder of Qaddafi, asserted that: "If you look at the reality of how the situation was in Libya before the airstrikes, the UN encroachment and radicalisation of the militants, who are backed by the West, and compare the former condition of the country and the current one, then you will clearly realise that the country is today suffering from a range of serious 
problems which it has not experienced previously. Its infrastructure is entirely demolished, military forces are walking in the streets, attacking people and even killing them, and they do whatever they like to. Many things have been changed, but not for the good." 32

Radicalisation and violence is significantly increasing in other countries as well. According to the Egyptian Centre for Economic and Social Rights (ECESR), since the 3 July military coup until 11 November 2013, 2,665 people were killed in Egypt. Statistics up until 3 December also show that as many as 16,000 were injured in violence which swept the country. 13,145 arrests took place in 718 incidents. ${ }^{33}$

Lastly, I strongly believe that Islam played no major role in initiating of the Arab Spring. The movement was led by civil society, especially the youth, and it was widely spread across all strata of the population, including non-Muslims and atheists, in their demand for accountability and good governance. The Arab Spring, yet, opened a door for the Islamic parties to come to power in a democratic way through the ballot box. Their message that Islam stands for just, accountable and consultative governance became the most essential aspirations of the masses, who were suffering from suppression and dictatorship for many long years. Public demand of the Arab nations at that stage, in fact, consisted not in choosing between secularism and an Islamic state but between corrupt governments and a clear economic agenda on how to attain social justice. The challenges, however, faced by the newly elected Islamic parties in Egypt, Tunisia or Libya, were too heavy and complicated. So far, the Renaissance Party of Tunisia alone is partly successful in facing these challenges. The so-called "neofundamentalists" lacked experience, time and internal as well as international support to find effective and quick solutions to economic and social problems of their peoples. They were unable to implement the principles and objectives of governance as outlined in the Qur'an.

International actors also played a role in the general lack of success of the Islamists, especially in Egypt. In fact, the West has perused its interests in the region both openly and covertly for decades, while endlessly maintaining that it calls for individual freedoms, democratic values and respect for public will. As Ahmad Chaker Jomaa, head of Journalism for the Federation of Student Islamic Societies (FOSIS), points out, the West would much prefer dealing with tyrannical military dictatorships (as shown by their historical support for Khalifa Haftar of Libya), rather than dealing with governments which are elected to represent the will of their people. ${ }^{34}$ It is why the international community turned a blind eye when the democratically elected head of state, Mohamed Morsi, was so ruthlessly overthrown in Egypt by military coup. The present political scene of the world reveals that we are witnessing a period of turmoil with the 
re-distribution of natural resources and strategic regions among the superpowers. People living in these underdeveloped areas will once more suffer because of the rich resources or strategic locations of their native lands.

It appears that the genuine desire of the majority of the Arab people in the wave of upheavals across the region has been for the establishment of good governments, which will enforce justice, equality and harmony, through democratic means. Islamic principles of governance have a potential to guide the people in building successful democratic nations in the region. Yet, without an alliance with other secularist parties of the country, and the full exertion for the Islamic principles in governance such as pluralism, egalitarianism, and freedom of speech and expression, the electoral victory of the Islamist parties alone will not provide substantial solutions to problems of the MENA region.

\section{Conclusion and Recommendations}

After a brief evaluation of the origins and consequences of the Arab Spring through highlighting the higher objectives of the Shariah in governance, as well as the basic rights and responsibilities of the citizens and the rulers in Islam, the paper suggests the following conclusions and recommendations.

Firstly, there is no essential incompatibility between the ultimate aims of the good governance paradigm and the Islamic political theory envisaged in the Qur'an and Sunna. Islamic principles, as embedded in the text and traditions, are conducive to democratic thought and good governance in many compelling ways. Securing peace, harmony, social stability and fairness are the primary objectives of governance in Islam. To achieve these goals, the government must ensure the rights of every individual under its authority, and should secure public participation in decision-making. In addition, the Qur'anic devices of the citizens' rights to criticise the authorities, to participate in the electoral process and consultation $(s h \bar{u} r \bar{a})$, and freedom of expression and speech provide an appropriate space for constructive improvements in state affairs.

Secondly, the Arab Spring was a manifestation of the absence of good governance, including its main components such as democracy, moderation, liberalism and justice, in the MENA region. The majority of the current nationstates in the Muslim world are far distant from achieving the primary objectives of Islam in governance. They failed to implement the potential and competence of the principles and objectives of governance outlined in the Qur'an. The citizens are entirely deprived from having an opportunity to amend the unfair systems through the peaceful means endorsed by the Shariah, such as by participation in fair elections, consultation and the assessment of the conduct of the government.

At the same time, rapid political and social transformations are commonly not for the benefit of the people. The Arab Spring is still unfolding and the 
uncertainties will be clarified in the course of time. Yet, at this moment, its negative consequences such as widespread bloodshed, human insecurity, injustice, nepotism, dismay and many other social ills are exceeding the positive ones. Healing of the hurts of the Arab Spring requires a prolonged period of time.

Lastly, it seems that implanting of Western-style democratic mechanisms alone may not cure the ills of the Muslim world. Stability and progress in the region depends mainly on the aptitude of the governments to create a milieu of public trust, devotion, appreciation and sincerity between the political elite and the people. To succeed, the governments should learn to respond to the needs and benefits of their own people. They should find effective and quick solutions to economic and social problems of their people. Consideration of public welfare and public interest, and protection of the rights of the citizens and human dignity is the main solution for stability in the MENA region.

The paper proposes the following policy recommendations:

- Evils of corruption, nepotism, intolerance, tribalism, and political and economic injustice should be prevented by the authorities as being extremely harmful for the well-being and security of society, and its stability. The government must guarantee the rights of every citizen under its authority, regardless of their gender, age, and religious, social and ethnic backgrounds.

- Militarism and violence, whether by individuals or states, must be brought under control through understanding the authentic Islamic principles in governance. Moderation and balance (wasatiyyah) approach must be implemented by the citizens and governments as a valuable legal guideline in the way of achieving good governance in the MENA region. Governments should accept peaceful, fair-minded and just rule in order to prevent revolutions and other types of public havoc.

- The will and rights of the citizens should not be neglected or interfered with by external and internal actors. Governments must ensure a platform for the youth and women to participate in decision-making. The promising potential of youth in the MENA region should be recognised and directed in a correct manner through proper education, respect and supervision.

- Muslim religious leaders, judges, ulama, Muftis and associations must concentrate on achieving a better understanding of the objectives and principles of governance in Islam at governmental and public levels. In order to heal the wounds and negative outcomes of the Arab Spring, they must publically condemn all types of violence, corruption, discrimination and rivalry among different madhāhib, religions, tribes and nations. 
- The media and educational system should be utilised actively for raising public awareness. The Islamic concepts of governance and citizens' rights could be included in university curricula, and textbooks should be prepared to train the Muslim youth to adopt more peaceful and harmonious ways of life.

\section{Notes}

* Elmira Akhmetova, a Tatar scholar from Russia, is Research Fellow at IAIS Malaysia. She has published a number of academic articles, book chapters and monographs on the issues of Islamic history, interfaith dialogue, Islamic political thought and civilisational studies. (Email: elmira@iais.org.my)

1. Rufus Fears, "Is Democracy coming to the Middle East?," Oklahoma Council of Public Affairs, <http://www.ocpathink.org/articles/1117> accessed 4 June 2014.

2. Declan McCullang, "Islam and the Arab Revolutions," The Economist, <http:// www.economist.com/node/18486005> accessed 3 June 2014.

3. See, $<$ http://www.ikhwanweb.com/article.php?id=29405 > accessed 4 June 2014.

4. Reuters, "Muslim Brotherhood Trial: Egypt Court Sentences 529 Morsi Supporters to Death," <http://www.huffingtonpost.com/2014/03/24/muslimbrotherhood-trial-egypt_n_5019909.html> accessed 4 June 2014.

5. World Bank, Sub-Saharan Africa: From Crisis to Sustainable Growth (Washington: World Bank, 1989); and Tom Pierre Najem, "Good Governance: The Definition and Application of the Concept" in Tom Pierre Najem, and MartinHetherington (eds.), Good Governance in the Middle East Oil Monarchies (London: RoutledgeCurzon, 2003), 1-2.

6. Ibid., 2; United Nations Development Programme, Public Sector Management, Governance and Sustainable Human Development (New York: UNDP, 1995); and International Monetary Fund, "IMF Adopts Guidelines Regarding Governance Issues" (Washington, DC: International Monetary Fund, 1997).

7. Mohamad Hashim Kamali, "Siyāsah shar'iyah or the Policies of Islamic Government," The American Journal of Islamic Social Sciences, vol. 6, no. 1 (1989), 60-61.

8. Ibid., 61 .

9. Mohammad Hashim Kamali, Freedom, Equality and Justice in Islam (Kuala Lumpur: Ilmiah Publishers, 2002), 143.

10. Ibid., 142.

11. Ibrahim M. Zein, Abdullah Al-Ahsan and Muhammad Arif Zakaullah, "Qur'anic Guidance on Good Governance" in Abdullah Al-Ahsan and Stephen B. Young (eds.), Guidance for Good Governance: Explorations in Qur'anic, Scientific and Cross-cultural Approaches (Kuala Lumpur: IIUM Press, 2008), 36.

12. Mohammad Hashim Kamali, Citizenship and Accountability of Government: An Islamic Perspective (Kuala Lumpur: IAIS \& Ilmiah Publishers, 2013), 198-199.

13. Ibid., 203.

14. See Mūsā Jārullāh, Al-Washī'ah fì Naqdi 'Aqāid al-Shī'ah (Cairo: Maktabāt alKullīyah al-Azhāāīyyah, 1984), 78.

15. Hady Ali and Mohamed Mostafa, "History of Islamic Politics: Judges vs. Rulers," Onislam, <http://www.onislam.net/english/politics/transnational/472171judiciary-and-political-power-in-islamic-history.html> accessed 14 May 2014. 
16. See, S.V.R. Nasr, "European Colonialism and the Emergence of Modern Muslim States," in The Oxford History of Islam, edited by John Esposito, Oxford Islamic Studies Online, <http:/www.oxfordislamicstudies.com/article/book/ islam-9780195107999/islam-9780195107999-chapter-13> accessed 13 May 2014.

17. Ibid.

18. "Democracy Index 2010," Economist Intelligence Unit, <http://graphics.eiu. com/PDF/Democracy_Index_2010_web.pdf> accessed 20 May 2014.

19. See, Elmira Akhmetova, "Women and Corruption," Islam and Civilisational Renewal, vol. 5, no. 2 (April, 2014), 273.

20. Zein, Al-Ahsan and Arif Zakaullah, "Qur'anic Guidance on Good Governance," 36.

21. See, Mohammad Hashim Kamali, Citizenship and Accountability of Government: An Islamic Perspective (Kuala Lumpur: IAIS \& Ilmiah Publishers, 2013), 147.

22. Ibid., 157.

23. See, Ibid., 160-162 and 166-168; and Amin Ahsan Islahi, "Conditions and Limits of Obedience to the Rulers," A Monthly Islamic Journal Renaissance, $<\mathrm{http}$ ://www. monthly-renaissance.com/issue/content.aspx?id=469> accessed 22 May 2014.

24. Kamali, Citizenship and Accountability of Government, 167.

25. Muslim, Mukhtașar Șah̄ị Muslim, 334, hadith 1235.

26. Tabrīzī, Mishkāt, vol. 2, hadith 3521; see also, Kamali, Citizenship and Accountability of Government, 167.

27. The term 'Arab Spring' was coined by the American political journal Foreign Policy to denote the chain of revolutionary upheavals and public havoc happening in the Middle Eastern and North African (MENA) region since October 2010. In fact, the notion 'spring' was first used in reference of the 'The Spring of Nations,' describing European revolutions of 1848. Later, it was used most prominently to describe a series of reforms taken within the period of 1966-1968 in Czechoslovakia that would later be reversed by the Soviet invasion of the country in 1968. See, Joseph Massad, "The Arab Spring and Other American Seasons," Aljazeera, $<$ http://www.aljazeera.com/indepth/opinion/2012/08/201282972539153865. html $>$ accessed 3 June 2014; and Marc Lynch, "Obama's 'Arab Spring?", Foreign Policy, $<\mathrm{http}$ ://mideastafrica.foreignpolicy.com/posts/2011/01/06/ obamas_arab_spring $>$ accessed 3 June 2014.

28. McCullang, "Islam and the Arab Revolutions."

29. Barbara Surk, "Activists: Death Toll in Syria's War Tops 160,000," The Morning Journal, $<$ http://www.morningjournal.com/general-news/20140519/activistsdeath-toll-in-syrias-war-tops-160000> accessed 28 May 2014.

30. Sarkis Abu-Zayd, "The Resurgence of Arab Tribalism," AlMonitor: The Pulse of the Middle East, <http://www.al-monitor.com/pulse/politics/2012/04/willtribalism-inherit-political.html> accessed 28 May 2014.

31. See, "The Return of Gaddafi," Islam 21 Century, <http://www.islam21c.com/ politics/the-return-of-gaddafi $>$ accessed 28 May 2014.

32. See, $<$ http://russian.rt.com/article/4481> accessed 2 June 2014.

33. "Over 2,600 killed in Egypt since coup," World Bulletin, <http://www. worldbulletin.net/?aType=haber\&ArticleID=126126> accessed 2 June 2014.

34. See, "The Return of Gaddafi." 